\title{
PEMBELAJARAN PENDIDIKAN JASMANI BERBASIS MULTIASPEK, KOLABORATIF, DAN SINTESIS KEUNGGULAN SUMBER BELAJAR
}

\author{
Agus Kristiyanto \\ FKIP Universitas Sebelas Maret (e-mail: aguskriss@yahoo.co.id; \\ HP: 081329040035)
}

\begin{abstract}
The Learning of Physical Education Based on Multi-Aspect Competence, Collaboration, and Synthesis of Learning Resource Advantages. This study aims to: (1) sharpen the pragmatic aspects of a model for briefing physical education student-teachers on their competence; (2) improve the institutional policy concerning ways of briefing them on their competence in physical education oriented to the present conditions; (3) develop the substance of the physical education microteaching; (4) improve the recognition of expertise from peers; and (5) map the networking of the partner institutions. This study employed a combination of methods consisting of a library study, descriptive survey, and action research. The data were collected through questionnaires, in-depth interviews, and focus group discussions. The findings show that the briefing model should comprise (1) multi-aspect competence, i.e. pedagogic, personal, professional, and social aspects; (2) collaboration by involving other relevant and competent parties; and (3) learning-resource sharing by making use of advantages of learning resources in the campus and partner schools.
\end{abstract}

Keywords: learning of physical education, multi-aspect competence, collaboration, learning-resource sharing

\section{PENDAHULUAN}

Sebagaimana layaknya institusi formal yang berbentuk LPTK (Lembaga Pendidikan Tinggi Tenaga Kependidikan), Jurusan Pendidikan Olahraga dan Kesehatan (JPOK) Fakultas Keguruan dan Ilmu Pendidikan Universitas Sebelas Maret Surakarta (FKIP UNS) mengemban tugas dalam memproduk tenaga pengajar pendidikan jasmani. Kebijakan apa pun yang ditempuh bermuara pada upaya strategis mencetak lulusan yang memiliki kompetensi profesional pengajar pendidikan jasmani yang memadai dan memiliki daya saing tinggi. Pengayaan bekal kompetensi di- lakukan dengan menyajikan kurikulum yang berbasis pada nilai-nilai fundamental pembelajaran pendidikan jasmani. Fokus pembenahan tentunya akan lebih mengarah pada usaha revitalisasi kegiatan pengajaran mikro. Inti kegiatan pengajaran mikro adalah untuk memberikan bekal yang cukup kepada mahasiswa calon guru terutama mengenai penguasaan sendi-sendi kompetensi, yang meliputi: kompetensi pribadi, kompetensi profesional, kompetensi pedagogi, dan kompetensi sosial. Sementara itu institusi harus selalu mendapatkan feedback dari kegiatan yang dilaksanakan tersebut. 
Pembekalan bagi calon guru pendidikan jasmani melalui program pengajaran mikro yang lebih "canggih" dimaksudkan sebagai langkah untuk solusi jangka panjang dalam meminimalkan permasalahan akut dalam pembelajaran pendidikan jasmani. Permasalahan akut yang terjadi dalam praktik pembelajaran pendidikan jasmani terutama terkait dengan keterbatasan para guru untuk mengembangkan proses pembelajaran yang kreatif dan inovatif. Dalam kenyataannya, sebagian besar guru menerapkan pembelajaran yang membosankan. Para guru pendidikan jasmani pada umumnya memiliki kecenderungan menggunakan cara yang sama untuk mengajar pendidikan jasmani. Hal tersebut bukan sekadar menjadikan kesan mengajar pendidikan jasmani sebagai aktivitas rutin yang membosankan, tetapi juga menjauhkan dari praktik pembelajaran yang bersifat kreatif dan inovatif. Oleh karena itu, inovasi dan pengembangan kreativitas dalam pembelajaran pendidikan jasmani merupakan sebuah tantangan besar bagi setiap guru pendidikan jasmani. Inovasi dan kreativitas tersebut merupakan kata kunci untuk menjadikan praktek pembelajaran sebagai sesuatu yang menarik dan memiliki manfaat dalam pencapaian tujuan pendidikan dalam arti yang sebenarnya.

Kegiatan microteaching merupakan ajang yang strategis bagi para mahasiswa untuk mendapatkan bekal kompetensi yang memadai, dalam kenyataannya praktik yang terjadi belum tentu mengarah pada upaya konkret pengayaan bekal kompetensi yang diharapkan. Hal tersebut tentunya terkait de- ngan kendala-kendala, yang meliputi: (1) rutinitas yang menjemukan; (2) jenis kompetensi yang kurang jelas bagi mahasiswa; (3) komitmen dosen pembimbing yang kurang kuat; (4) kurangnya kesempatan praktik; (5) pemanfaatan infrastruktur yang kurang memadai; dan (6) terisolasinya tuntutan sekolah latihan atas kompetensi yang seharusnya dimiliki oleh setiap praktikan atau mahasiswa calon guru.

Model pembekalan yang sifatnya formal institusional harus dilakukan untuk membangun terbentuknya kompetensi pembelajaran dengan mensintesiskan potensi metakognisi dosen, guru, serta ekspektasi mahasiswa. Proses sintesis tersebut dilakukan untuk menyusun model pembelajaran pendidikan jasmani yang berorientasi pada Pembelajaran Aktif, Inovatif, Kreatif, Efektif, dan Menyenangkan (Paikem).

Kegiatan yang telah dilaksanakan adalah kegiatan penelitian pendahuluan yang dilaksanakan oleh tim peneliti setiap tahun mulai tahun 2003 hingga 2009. Penelitian terkait dengan kajiankajian untuk meletakkan landasan faktual empirik terkait dengan proses pembekalan kompetensi pembelajaran pendidikan jasmani. Kegiatan penelitian tentang pembekalan kompetensi yang telah dilaksanakan tim adalah: (1) pemantapan keterampilan mengajar (teaching skill) pendidikan jasmani melalui penerapan model sibernetika tahun 2003; (2) peningkatan kompetensi mengajar pendidikan jasmani melalui perbaikan pilihan spektrum gaya mengajar (the spectrum of teaching style) model mosston tahun 2004; (3) kualitas harapan dan kesiapan mahasiswa prodi 
penjaskesrek dalam program pengalaman lapangan (PPL) Tahun 2005; (4) diagnosis kesulitan penguasaan komponen keterampilan mengajar pada Mahasiswa JPOK FKIP UNS tahun 2006; (5) perbaikan keterampilan mengajar mahasiswa praktikan PPL pendidikan jasmani melalui pilihan spektrum gaya mengajar yang sesuai tahun 2007; (6) kombinasi pilihan umpan balik dan spektrum gaya mengajar (penerapan feedback dan teaching style pada latihan praktik mengajar pendidikan jasmani mahasiswa Jurusan POK FKIP UNS tahun 2008; (7) kemampuan peer observation, aspek jenis kelamin dan pengalaman kerja (kajian model inputfeedback pengajaran mikro pada mahasiswa kualifikasi guru pendidikan jasmani tahun 2009.

Kegiatan yang akan dilaksanakan adalah untuk menindaklanjuti rekomendasi penelitian yang telah dilakukan sebelumnya (kurun 2003 s/d 2009). Rekomendasi tersebut sekaligus menjadi target kegiatan yang direncanakan berisi tentang: (1) pembekalan kompetensi pembelajaran pendidikan jasmani merupakan seperangkat skill yang tidak cukup dibekalkan secara teoretis, tetapi harus diskenariokan dalam perkuliahan praktik penguasaan dalam kompetensi multiaspek, yaitu kompetensi kepribadian, pedagogi, profesional, dan sosial; (2) model pembekalan kompetensi seharusnya melibatkan pihak-pihak terkait (stakeholder) untuk menghindarkan proses pembekalan yang statis dan dangkal, sehingga pembekalan kompetensi yang ideal dilaksanakan dengan prinsip kolaborasi; (3) optimalisasi pembekalan dilakukan secara kreatif de- ngan cara memadukan atau mensintesiskan keunggulan-keunggulan yang dimiliki oleh institusi dan pihak terkait (stakeholder) dalam bentuk sharing of learning resources; (4) Kata kunci dalam mengoptimalkan proses pembekalan kompetensi pembelajaran pendidikan jasmani adalah: kompetensi multiaspek - berprinsip kolaborasi - mensintesiskan keunggulan sumber belajar yang ada. Berdasarkan hal tersebut kegiatan yang dilaksanakan akan memfokus pada penyusunan: "Prototipe Pembekalan Kompetensi Pembelajaran Pendidikan Jasmani berbasis Multiaspek, Kolaboratif, dan Sintesis Keunggulan Sumber Belajar".

Kebaharuan penelitian yang diusulkan terkait dengan permasalahan: (1) substansi; dan (2) metodologisnya. Secara substansial dan metodologis hal ini merupakan babakan baru dalam bidang penelitian. Secara substansial penelitian ini mengkaji tentang permasalahan kompetensi pembelajaran pendidikan jasmani yang memiliki cakupan yang sangat unik, tetapi mengandung hal yang bersifat multiaspek, yaitu kompetensi kepribadian, kompetensi profesional, kompetensi pedagogi, dan kompetensi sosial. Penelitian ini juga memiliki sisi kebaharuan dalam hal model pembekalan yang memadukan fungsifungsi esensial dari perlunya kolaborasi dan sintesis keunggulan-keunggulan sumber belajar yang dimiliki oleh pihak institusi perguruan tinggi maupun pihak kolaborator dan stakeholder. Substansi penelitian yang menukik pada kajian kompetensi merupakan kajian yang aktual terutama dalam era pembenahan dan arah pengembangan pro- 
duk profesi guru ke depan yang lebih bermutu.

Secara metodologis dikatakan memiliki kebaharuan dalam bidang penelitian karena prosedur penelitian yang diterapkan merupakan fusi dari beberapa pendekatan penelitian yang relevan dengan tujuan yang akan dicapai. Asas-asas multiple researches dikembangkan dalam penelitian ini karena luaran penelitian cukup bervariasi, yaitu berupa tagihan buku ajar dan publikasi ilmiah, rumusan kebijakan institusional, pengakuan kepakaran dari peers, dan pengembangan kemitraan.

Salah satu alasan mengapa multiple researches amat menarik, karena banyak kalangan peneliti cenderung bersikap ekstrem terhadap paradigma penelitian tertentu dan kurang membuka diri pada paradigma lain. Padahal keterikatan kepada salah satu perspektif metode akan membuat disiplin ilmu mengalami kemandekan. Jalan keluarnya adalah mengenyahkan pikiran yang memenjarakan bahwa metodologi yang digunakan adalah satu-satunya metodologi yang benar (Ambo Upe \& Damsid, 2010).

Hasil kegiatan penelitian jika diterapkan akan memberikan manfaat, terutama untuk: (1) memperoleh temuan-temuan penelitian secara faktualempirik yang dapat menyelesaikan masalah pengembangan kualitas layanan profesi, terutama dalam aspek: penyusunan model pembekalan kompetensi pembelajaran pendidikan jasmani yang selama ini belum dilakukan secara optimal oleh LPTK yang dimiliki oleh pemerintah; (2) memberikan sumbang- an langsung terhadap pencapaian indikator sebagaimana dimaksud dalam RENSTRA; (3) memberikan peluang yang lebih tinggi bahwa kualitas dan kompetensi dosen tim pelaksana kegiatan akan lebih baik; (4) dapat meningkatkan kualitas materi perkuliahan dengan adanya pengayaan dengan cara dimasukkannya hasil-hasil penelitian subagai materi bahan ajar; dalam hal ini untuk meningkatkan relevansi dan keluasan cakupan materi matakuliah pengajaran mikro pendidikan jasmani; (5) mendorong perguruan tinggi untuk dapat memanfaatkan fasilitas dosen dan laboratorium selain untuk proses pembelajaran dapat dimanfaatkan untuk penelitian yang dapat berguna bagi masyarakat; (6) dapat mendongkrak publikasi artikel ilmiah dalam jurnal terakreditasi nasional dan internasional, terutama terkait dengan pengembangan kompetensi pembelajaran pendidikan jasmani yang inovatif dan efektif.

\section{METODE}

Kegiatan yang dikembangkan merupakan kegiatan penelitian yang menerapkan berbagai pendekatan penelitian. Pendekatan yang digunakan meliputi: studi kepustakaan, survei deskriptif, penelitian tindakan kelas (PTK) serta tahap-tahap tertentu dari sebuah penelitian tentang analisis kebijakan, khususnya analisis kebijakan institusional terkait dengan model pembekalan kompetensi pembelajaran pendidikan jasmani di JPOK FKIP UNS.

Secara gamblang, kombinasi metode penelitian ditempuh untuk mengakomodasikan berbagai temuan-temu- 
an penting penelitian relevan yang telah dilakukan sebelumnya oleh tim peneliti. Alur penelitian diawali dengan survey deskriptif untuk mendapatkan informasi aktual dan faktual terkait dengan respon mahasiswa JPOK FKIP UNS. Respon harus diungkap untuk memetakan apresiasi dasar keprofesian dan kesiapan pasca pengajaran mikro. Hasil survei terhadap sejumlah 54 orang mahasiswa dijadikan sebagai pertimbangan dasar penyusunan Standard Operational Procedure (SOP) dalam tahap analisis kebijakan yang dilakukan di skala institusi mikro, yakni kebijakan mikro pada tataran program studi.

Tahap selanjutnya adalah merekam dan mendeskripsikan unit-unit kompetensi multiaspek yang dilakukan atau tidak dilakukan oleh praktikan. Rekamandan pendeskripsian tersebut merupakan bagian awal dari pelaksanaan penelitian tindakan kelas di sekolah mitra. Pemodelan pembekalan pembelajaran pendidikan jasmani disusun di sekolah mitra dalam sesi-sesi latihan praktik mengajar yang melibatkan peran opti- mal praktikan, dosen pembimbing dan guru pamong. Pemodelan disosialisakin melalui tahap diseminasi. Alur kegiatan dapat digambarkan dalam bentuk skema pada Gambar 1.

Luaran Hibah Kompetensi, yaitu berupa: (1) kumpulan publikasi ilmiah di jurnal terakreditasi; (2) kemanfaatan teknologi tepat guna atau rekayasa sosial/ rumusan kebijakan institusional terkait pembelajaran mikro; (3) naskah atau Buku Ajar yang berupa draft buku tentang prototipe pembekalan kompetensi pembelajaran pendidikan jasmani; (4) peningkatan pengakuan kepakaran oleh peers atau komunitas sejenis di luar institusi; dan (5) berkembangnya jejaring kerja sama antar peneliti, antarpelaksanaan kegiatan dan antarlembaga.

Secara metodologis, hal esensial yang perlu dirumuskan dalam penelitian multi tahun ini adalah rumusan tentang substansi riset. Rumusan substansi mengarah pada prioritas atau pemfokusan substansi kajian pada tahun ke-1, ke-2, dan ke-3 seperti tampak pada Tabel 1.

Tabel 1. Prioritas atau Pemfokusan Substansi Kajian tahun ke-1, ke-2, dan ke-3

\begin{tabular}{|c|c|c|c|c|c|c|c|c|c|}
\hline & \multicolumn{3}{|c|}{$\begin{array}{l}\text { PAIKEM } \\
\text { (Metodik) }\end{array}$} & \multicolumn{3}{|c|}{$\begin{array}{l}\text { PAIKEM } \\
\text { (Media) }\end{array}$} & \multicolumn{3}{|c|}{$\begin{array}{c}\text { PAIKEM } \\
\text { (Evaluasi/Asesmen) }\end{array}$} \\
\hline & $\begin{array}{l}\text { Tahun } \\
\text { I }\end{array}$ & $\begin{array}{l}\text { Tahun } \\
\text { II }\end{array}$ & $\begin{array}{c}\text { Tahun } \\
\text { III }\end{array}$ & $\begin{array}{l}\text { Tahun } \\
\text { I }\end{array}$ & $\begin{array}{c}\text { Tahun } \\
\text { II }\end{array}$ & $\begin{array}{c}\text { Tahun } \\
\text { III }\end{array}$ & $\begin{array}{l}\text { Tahun } \\
\text { I }\end{array}$ & $\begin{array}{c}\text { Tahun } \\
\text { II }\end{array}$ & $\begin{array}{c}\text { Tahun } \\
\text { III }\end{array}$ \\
\hline $\begin{array}{l}\text { Kompetensi } \\
\text { Multiaspek }\end{array}$ & $\sqrt{ }$ & & & & $\sqrt{ }$ & & & & $\sqrt{ }$ \\
\hline Kolaborasi & $\sqrt{ }$ & & & & $\sqrt{ }$ & & & & $\sqrt{ }$ \\
\hline $\begin{array}{l}\text { Sintesis } \\
\text { Sumber } \\
\text { Belajar }\end{array}$ & $\sqrt{ }$ & & & & $\sqrt{ }$ & & & & $\sqrt{ }$ \\
\hline
\end{tabular}




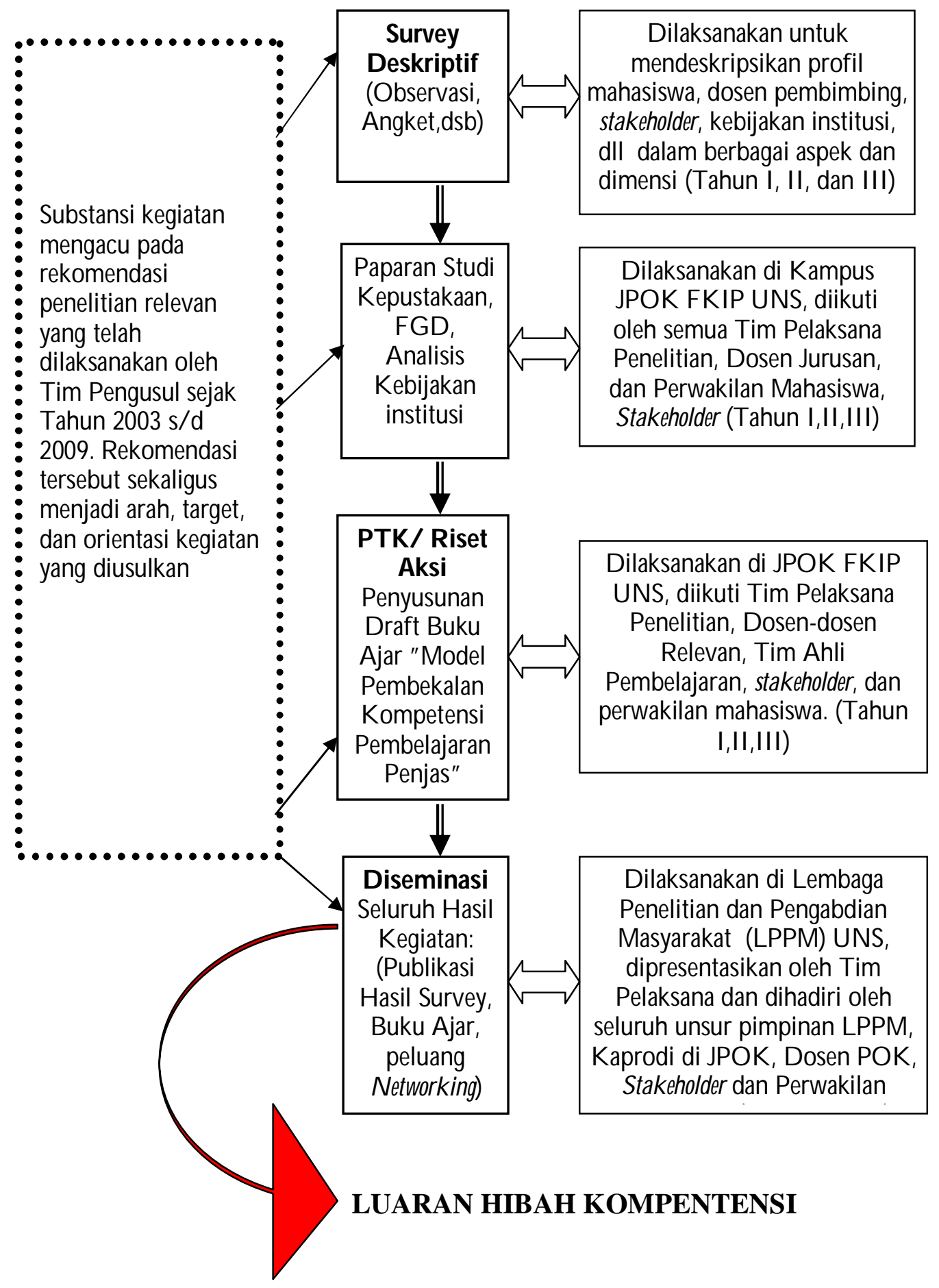

Gambar 1. Skema Alur Kegiatan 


\section{HASIL}

Pemetaan Studi Deskriptif Apresiasi dan Kesiapan Pasca Pengajaran Mikro Image dan Kecintaan terhadap Profesi Guru Pendidikan Jasmani

Respon dari 54 responden menunjukkan bahwa hanya sejumlah 5 orang yang meragukan kecintaannya terhadap profesi guru pendidikan jasmani. Sejumlah 23 orang mengakui cinta profesi guru pendidikan jasmani, sedangkan selebihnya yang berjumlah 26 orang sangat mencintai profesi guru pendidikan jasmani. Kecenderungan atas data tersebut adalah: setidak-tidaknya terdapat sejumlah 49 orang dari 54 orang responden yang mencintai profesi sebagai guru pendidikan jasmani. Artinya, responden yang mencintai profesi guru pendidikan jsmani adalah sebesar 90,7\%.

Kualitas harapan dan kesiapan pada pelaksanaan program pengalaman lapangan (PPL) khusus pendidikan jasmani berkaitan langsung dengan kecintaan atas profesi guru pendidikan jasmani. Kecintaan terhadap profesi guru pendidikan jasmani menjadi modal awal keberhasilan usaha mempersiapkan tenaga guru pendidikan jasmani. Kegiatan PPL memiliki inti tujuan untuk mempersiapkan lulusan JPOK FKIP UNS dalam mempersiapkan guru pendidikan jasmani yang berkompeten.

\section{Perkiraan Gambaran Awal tentang PPL}

Gambaran awal yang dimaksudkan adalah persepsi mahasiswa tentang PPL berdasarkan pemahaman mahasiswa sebelum melaksanakan kegiatan PPL. Gambaran tersebut banyak terbentuk sejak saat mahasiswa masih duduk di semester-semester awal, dan lebih intens lagi, terutama pada saat mengikuti matakuliah pengajaran mikro. Hal itu merupakan salah satu komponen penting dalam melihat kualitas harapan dan kesiapan mahasiswa dalam pelaksanaan PPL. Untuk itu, setidak-tidaknya ada tiga respon penting berekenaan dengan persepsi awal responden terhadap kesiapan pelaksanaan PPL: (1) bekal yang diperoleh selama PPL; (2) kesiapan PPL akibat mengikuti pengajaran mikro; dan (3) keyakinan bahwa PPL berlangsung lancar.

Pada pernyataan/pertanyaan angket tentang bekal yang diperoleh selama PPL, sejumlah 54 orang atau 100\% jumlah responden mengaku bahwa dengan PPL pendidikan jasmani dapat diperoleh bekal yang memadai sebagai calon guru pendidikan jasmani. Terhadap pernyataan/pertanyaan angket tentang bekal yang diperoleh selama mengikuti pengajaran mikro untuk kesiapan PPL, sejumlah 42 orang atau $77,8 \%$ dari jumlah responden mengaku bahwa dengan pengajaran mikro dapat diperoleh bekal yang memadai dalam rangka mempersiapkan diri mengikuti PPL.

Pada pernyataan/pertanyaan angket tentang keyakinan bahwa PPL dapat berlangsung lancar karena PPL hanya sebatas kegiatan formalitas rutin, 35 orang atau $64,8 \%$ dari jumlah responden mengaku ragu-ragu. 
Penilaian Mahasiswa atas Pelaksanaan Pengajaran Mikro

Penilaian mahasiswa (responden) terhadap pelaksanaan pengajaran mikro merupakan bagian terbanyak yang ditanyakan dalam angket. Setidak-tidaknya ada enam point penting pada bagian ini. Keenam hal penting tersebut berkenaan dengan tanggapan yang kekuatan responnya adalah (1) berharap banyak pada pengajaran mikro (53,7\%); (2) peran optimal dosen pembimbing $(77,8 \%)$; (3) penguasaan kompetensi bergantung pada usaha mahasiswa $(81,7 \%)$; (4) evaluasi dosen pembimbing objektif $(77,7 \%)$; (5) koreksi dosen pembimbing proporsional $(87,2 \%)$; (6) dosen pembimbing berperan dalam proses pembekalan $(87,0 \%)$.

Rekam Pengamatan Atas Bagianbagian Kompetensi Multi Aspek Pembelajaran Pendidikan Jasmani

Berikut ini hasil analisis tentang kesulitan penguasaan kompetensi pembelajaran bagian-bagian multi aspek pendidikan jasmani pada mahasiswa POK FKIP UNS tahun 2010.

- Komponen penyusunan rencana pengajaran berkenaan dengan: (1) penyusunan rencana yang sesuai format; (2) rencana urutan pelaksanaan; dan (3) rencana evaluasi.

- Dalam hal penyusunan rencana pengajaran pendidikan jasmani sesuai dengan format, maka terdapat kecenderungan berimbang antara yang menganggap sebagai sesuatu yang sulit dan sebagai sesuatu yang mudah. Jumlah res- ponden yang menganggap sulit sebesar 61,1\%.

- Dalam hal rencana urutan pelaksanaan, 55,6\% responden menganggap bahwa menyusun rencana urutan pelaksanaan pengajaran tersebut merupakan sesuatu yang mudah dilakukan.

- Dalam hal menyusun rencana evaluasi, 38,9\% responden menganggap komponen keterampilan mengajar tersebut sebagai sesuatu yang mudah. Bila sejumlah 16 orang responden yang berada pada posisi ragu-ragu dianggap condong ke arah kelompok yang menganggap mudah, maka jumlah responden yang menganggap menyusun rencana evaluasi sebagai hal yang mudah menjadi sebesar 68,5\%.

- Komponen keterampilan "Membuka dan menutup Pelajaran" merupakan komponen yang dianggap mudah dikuasi berdasarkan tanggapan $\mathbf{8 1 , 5 \%}$ responden.

- Sebesar 75,9\% responden menganggap bahwa keterampilan "memimpin pemanasan" sebagai suatu komponen keterampilan yang mudah untuk dikuasai.

- Komponen pertama, keterampilan yang dianggap sulit dalam penguasaannya adalah "Memberi Umpan Balik". Sejumlah $\mathbf{7 9 , 6 \%}$ responden menganggap keterampilan memberi umpan balik sebagai sesuatu yang sulit dikuasai.

- Komponen kedua, keterampilan yang dianggap sulit dalam penguasaannya adalah "Memilih dan Menetapkan Metode/Gaya Mengajar". Sebesar $\mathbf{7 4 , 1 \%}$ responden menganggap kete- 
rampilan memilih dan menetapkan metode/gaya mengajar sebagai sesuatu yang sulit dikuasai.

- Komponen ketiga, keterampilan yang dianggap sulit dalam penguasaannya adalah "Membuat Variasi". Sebesar $\mathbf{7 0 , 4} \%$ responden menganggap keterampilan membuat variasi sebagai sesuatu yang sulit dikuasai.

- Komponen keempat, keterampilan yang dianggap sulit dalam penguasaannya adalah "Melakukan Evaluasi yang Sesuai". Sebesar $\mathbf{7 2 , 2} \%$ responden menganggap keterampilan melakukan evaluasi yang sesuai sebagai sesuatu yang sulit dikuasai.

Rekam Pengamatan Praktik Pembelajaran Pendidikan Jasmani di Sekolah Mitra

Deskripsi data penelitian pada awalnya mengacu pada hasil observasi mengenai praktik latihan mengajar pada awal pelaksanaan PPL di Sekolah Latihan. Observasi terhadap para praktikan terbatas pada praktikan di SMK Negeri 1 Sukoharjo yang terdiri dari 6 orang. Observasi tersebut terutama terkait dengan upaya merekam kemampuan praktikan dalam hal penguasaan komponen keterampilan mengajar, termasuk di dalamnya adalah aplikasi gaya mengajar yang sesuai. Pilihan gaya mengajar berkaitan dengan perubahan spektrum pembagian peran yang teralokasikan oleh skenario latihan mengajar pendidikan jasmani.

Hasil catatan dominan yang dapat diobservasi terhadap 4 (empat) mahasiswa JPOK FKIP UNS Semester VII yang menempuh PPL di SMK Negeri 1 Sukoharjo dan SMP Negeri 3 Sukoharjo Tahun 2010 dapat dilihat pada Tabel 2.

\section{Hasil Penelitian Tindakan Kelas di Sekolah Mitra}

Hasil observasi mengenai kemampuan para mahasiswa praktikan menggeser peran antara guru dan siswa dalam suatu proses transaksi pembelajaran pendidikan jasmani, bermanfaat untuk bahan diagnosis dan prognosis rencana tindakan di sekolah latihan. Tindakan peningkatan kompetensi mengajar pendidikan jasmani dilakukan melalui perbaikan pilihan spektrum gaya mengajar model Mosston. Selama proses peningkatan kompetensi tersebut, para observer dan praktikan yang dikenai tindakan tentunya harus memulai dengan keadaan persepsi yang sama. Hal tersebut dilakukan dengan cara memberi bekal teoretis yang cukup kepada seluruh mahasiswa praktikan mengenai pilihan gaya mengajar dalam praktik mengajar.

Penguasaan konsep teoretis mengenai "pilihan gaya mengajar", bermanfaat sebagai landasan berpijak dalam tahap perencanaan peningkatan kompetensi. Observer dan praktikan secara bersama-sama merencanakan tindakan pengajaran pendidikan jasmani dengan memilih suatu gaya mengajar tertentu, setelah terlebih dahulu berdiskusi tentang apa yang seharusnya dilakukan. 
Tabel 2. Mahasiswa JPOK FKIP UNS yang PPL di SMK Negeri 1 Sukoharjo dan SMP Negeri 3 Sukoharjo Tahun 2010

\begin{tabular}{|c|c|}
\hline EPISODE & Observasi Kejadian dalam PBM \\
\hline $\begin{array}{l}\text { Pre- } \\
\text { Impact } \\
\text { (I) }\end{array}$ & $\begin{array}{l}\text { 1. Materi selalu mengacu pada GBPP yang telah diberikan oleh Guru } \\
\text { Pamong, sehingga mahasiswa praktikan tidak mengalami kesulitan } \\
\text { dalam memilih materi. } \\
\text { 2. Perencanaan tertulis sudah mengacu pada KBK, termasuk } \\
\text { merencanakan alat serta prosedur evaluasi yang harus dilakukan } \\
\text { dalam kegiatan latihan mengajar. } \\
\text { 3. Mahasiswa praktikan telah siap berperan sebagai guru sesuai } \\
\text { dengan jadwal yang telah ditetapkan bersama Guru Pamong di } \\
\text { Sekolah Latihan. }\end{array}$ \\
\hline & $\begin{array}{l}\text { 1. Pengelolaan Kelas pada umumnya kurang memperhatikan } \\
\text { penanganan individual, penanganan cenderung bersifat klasikal } \\
\text { dengan model interaksi satu arah. } \\
\text { 2. Kemampuan mengenali kekeliruan siswa sangat terbatas dan upaya } \\
\text { melibatkan siswa dalam proses umpan balik belum tampak. } \\
\text { 3. Pemberian contoh bersifat informatif secara standar namun kurang } \\
\text { memacu siswa untuk secara antusias mencoba berulang-ulang. } \\
\text { 4. Kemampuan mendeteksi keterlibatan siswa amat terbatas, melalui } \\
\text { model komando yang kaku. } \\
\text { 5. Peran guru sangat dominan dalam pengaturan proses pembelajaran } \\
\text { pendidikan jasmani, yang acapkali melakukan komando secara } \\
\text { berlebihan atas beberapa hal yang sebenarnya tidak perlu dilakukan } \\
\text { oleh guru.. } \\
\text { 6. Siswa sekadar mengikuti apa yang diperintahkan guru sampai hal } \\
\text { yang sangat kecil, seperti pengaturan urutan serta kebebasan } \\
\text { mencoba suatu gerakan keterampilan. } \\
\text { Pergeseran peran antara guru dan siswa pada setiap episode belum } \\
\text { dapat berlangsung, karena mahasiswa cenderung hanya } \\
\text { menggunakan satu gaya mengajar, yaitu gaya komando semata. }\end{array}$ \\
\hline $\begin{array}{l}\text { Post- } \\
\text { Impact } \\
\text { (III) }\end{array}$ & $\begin{array}{l}\text { 1. Penyampaian informasi kepada siswa hanya bersifat pesan panjang } \\
\text { yang berkesan kurang berharga. } \\
\text { 2. Evaluasi serta Umpan Balik yang disampaikan oleh guru cenderung } \\
\text { tidak ditangkap dengan perhatian yang memadai oleh siswa, karena } \\
\text { faktor kelelahan maupun kejenuhan. }\end{array}$ \\
\hline
\end{tabular}

Observasi penguasaan komponen keterampilan mengajar sebelum pe- laksanaan penelitian tindakan sebagaimana Tabel 3 berikut. 
Tabel 3. Observasi Penguasaan Komponen Keterampilan Mengajar

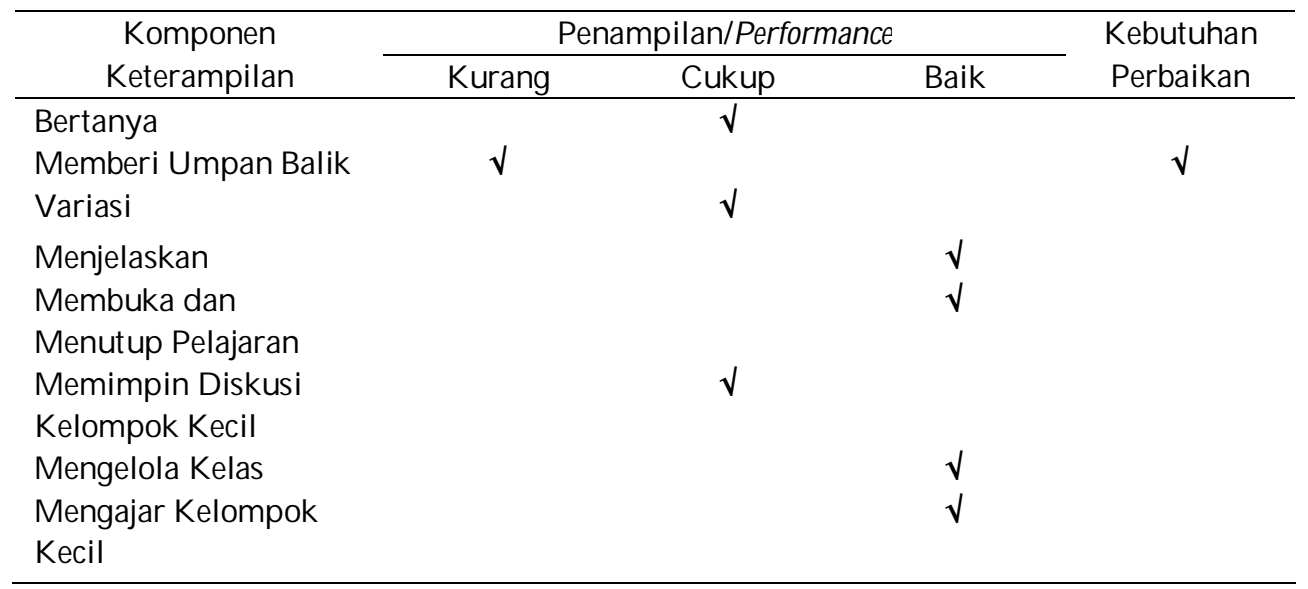

\section{PEMBAHASAN}

Kualitas harapan dan kesiapan mahasiswa dalam pelaksanaan kegiatan PPL pendidikan jasmani pada khususnya, setidak-tidaknya meliputi 3 (tiga) dimensi kualitas dan kesiapan, yaitu: (1) image dan kecintaan terhadap profesi guru pendidikan jasmani; (2) perkiraan gambaran awal tentang PPL; dan (3) penilaian mahasiswa atas pelaksanaan pengajaran mikro.

Berdasarkan dimensi image dan kecintaan terhadap profesi, setidaktidaknya terdapat $90,7 \%$ responden yang mencintai profesi guru pendidikan jasmani. Selebihnya yang sebesar 9,3\% tidak membenci profesi, namun meragukan kecintaannya terhadap profesi guru pendidikan jasmani.

Berdasarkan dimensi perkiraan awal mahasiswa terhadap pelaksanaan PPL, kesimpulan yang dapat diperoleh adalah (1) sebesar $100 \%$ jumlah responden atau seluruh responden mengaku bahwa dengan PPL pendidikan jasmani dapat diperoleh bekal yang memadai sebagai calon guru pendidikan jasmani; dan (2) sebesar $77,8 \%$ dari jumlah responden mengaku bahwa dengan pengajaran mikro dapat diperoleh bekal yang memadai dalam rangka mempersiapkan diri mengikuti PPL.

Berdasarkan dimensi penilaian mahasiswa atas pelaksanaan pengajaran mikro, beberapa kesimpulan yang dapatdiperoleh meliputi: (1) berharap banyak pada pengajaran mikro $(53,7 \%)$, (2) peran optimal dosen pembimbing (77,8\%), (3) penguasaan kompetensi bergantung pada usaha mahasiswa $(81,7 \%)$, (4) evaluasi dosen pembimbing obyektif $(77,7 \%)$, (5) koreksi dosen pembimbing proporsional $(87,2 \%),(6)$ dosen pembimbing berperan dalam proses pembekalan $(87,0 \%)$. 


\section{Diskusi Seluruh Siklus PTK dan Pemodelan}

Pembahasan hasil penelitian bersandar pada rancangan analisis data dan refleksi yang telah diuraikan di depan. Dasar acuan analisis adalah hasil-hasil refleksi setiap siklus dalam proses peningkatan kompetensi mengajar pendidikan jasmani melalui perbaikan pilihan spektrum gaya mengajar model Mosston yang sesuai diterapkan dalam praktik mengajar selama PPL.

Dari hasil seleksi dan pemfokusan masalah dalam praktik pembelajaran, beberapa kecenderungan penting yang dapat dikemukakan meliputi hal-hal sebagai berikut.

- Pilihan Spektrum gaya mengajar pendidikan jasmani disepakati dengan cara memilih spektrum gaya A - E, sedangkan gaya $\mathrm{F}-\mathrm{H}$ belum dapat dicoba untuk diaplikasikan oleh semua mahasiswa praktikan.

- Seluruh mahasiswa praktikan mengawali pilihan gaya mengajar dengan cara menguasai Gaya Komando (Gaya A) sebagai gaya yang wajib dipraktikkan oleh semua mahasiswa praktikan, untuk semua materi atau pokok bahasan.

- Gaya Komando (Gaya A) dilakukan oleh setiap mahasiswa praktikan dengan materi yang berbeda yang terdiri atas: permainan, senam, dan atletik, dengan memperhatikan jadwal serta acuan dalam GBPP Bidang Studi Pendidikan Jasmani, untuk strata kelas yang diajar oleh mahasiswa praktikan yang bersangkutan.
- Setelah Gaya Komando terkuasai dengan baik, maka pergeseran spektrum pilihan gaya untuk praktek selanjutnya diserahkan kepada setiap praktikan untuk menentukannya, berdasarkan kesepakatan dengan Guru Pamong, Dosen Pembimbing dan sesama praktikan.

Pembahasan hasil analisis di atas mengacu pada hasil refleksi tiap-tiap siklus. Disain penelitian tindakan ini terbagi ke dalam tiga siklus. Oleh karena itu, informasi tentang catatan refleksi dari ketiga siklus tersebut sudah merupakan suatu bahasan yang amat penting dari sebuah penelitian tindakan. Proses kolaborasi antara mahasiswa praktikan yang dikenai tindakan dengan observer yang terlibat secara kooperatif, menjadikan terbentuknya situasi kondusif bagi munculnya kompetensi yang diharapkan. Peningkatan kompetensi; khususnya kompetensi mengajar pendidikan jasmani melalui perbaikan pilihan spektrum gaya mengajar (The Spectrum of Teaching Style) terjadi karena ada sistem kontrol yang melekat selama proses pembentukannya. Tahapan-tahapan pada setiap siklus penelitian tindakan memang selalu bertujuan untuk perbaikan dan peningkatan kompetensi tersebut. Prinsip Better Student Learning terbentuk dalam proses maupun produk.

\section{PENUTUP}

Beberapa kesimpulan penting penelitian ini dapat diperoleh relevan dengan tujuan kegiatan yang telah diformulasikan pada bagian awal, yakni 
sebagai berikut.

- Penajaman aspek pragmatis model pembekalan kompetensi calon guru pendidikan jasmani, khususnya dalam pengembangan pembelajaran yang aktif, inovatif, kreatif, efektif, dan menyenangkan (Pakem/Paikem) terbukti sangat aplikatif dan implementatif dilakukan melalui azaz-azas pembekalan: (1) kompetensi multi aspek, yakni menyangkut aspek pedagogis, kepribadian, profesional, dan sosial; (2) kolaboratif, yakni proses pembekalan harus melibatkan pihak lain yang relevan dan kompeten; dan (3) sharing keunggulan sumber belajar, yakni memanfaatkan keunggulan sumber belajar yang ada di perguruan tinggi (kampus) dan keunggulan-keunggulan yang mungkin ada di sekolah mitra PPL.

- Pembekalan aspek metodik melalui penerapan berbagai spektrum gaya mengajar Mosston memiliki fungsi yang sangat nyata untuk menjadikan proses pembelajaran pendidikan jasmani lebih inovatif dan menyenangkan. Penerapan gaya Mosston yang berspektrum sesuai akan menimbulkan fungsi interakasi yang optimal antara guru, siswa dan materi pembelajaran pendidikan jasmani.

- Perbaikan bentuk dan arah kebijakan institusional terkait dengan cara-cara pembekalan kompetensi mengajar pendidikan jasmani yang berorientasi aspek kekinian, mengarah pada bagaimana memaksimalkan peran dosen pembimbing dan guru pamong dari sekolah mitra untuk menerapkan sistem magang profesi (PPL) yang menjadikan praktikan memiliki kompetensi multi aspek.

- Pengembangan substansi Matakuliah Pengajaran Mikro atau Microteaching pendidikan jasmani yang lebih aktual dan komprehensif sangat efektif dilakukan dengan cara penyusunan draft buku ajar teknologi pembelajaran pendidikan jasmani (metodik, media, dan assesmen) yang secara berkala disusun dan diperbaiki oleh team teaching pengajaran mikro di program studi. Dalam kegiatan hibah kompetensi tahun ke-1 telah berhasil memunculkan produk buku ajar tentang inovasi metodik. Sementara inovasi media pembelajaran pendidikan jasmani direncanakan pada tahun ke2. Inovasi asesmen pembelajarn pendidikan jasmani direncanakan pada tahun ke-3.

- Perbaikan pembekalan kompetensi pembelajaran pendidikan jasmani yang multi aspek juga sangat efektif dilakukan dengan pengembangan jejaring institusi mitra terutama pada tataran institusi pengguna atau stakeholder yang memiliki keunggulan dalam inovasi pembelajaran pendidikan jasmani.

\section{UCAPAN TERIMA KASIH}

Ucapan terima kasih kami sampaikan kepada : (1) Rektor, PR I, PR II, PR III, dan PR IV Universitas Sebelas Maret Surakarta: (2) Ketua dan Sekretaris LPPM UNS berikut seluruh stafnya; (3) Dekan FKIP UNS dan Ketua Jurusan POK FKIP UNS; (4) Kepala Sekolah SMK Negeri 1 Sukoharjo dan Kepala Sekolah SMP Negeri 3 Sukoharjo, beserta para guru pamong dan staf tata usaha di kedua sekolah tersebut; (5) 
Para kolega, Dosen Pembimbing Pengajaran Mikro dan PPL Pendidikan Jasmani; (6) Para mahasiswa peserta Program Pengajaran Mikro dan seluruh praktikan PPL penjas dari Jurusan POK FKIP UNS Tahun 2010; dan (7) Semua pihak yang membantu kelancaran pelaksanaan kegiatan penelitian ini.

\section{DAFTAR PUSTAKA}

Kristiyanto, Agus. 2000. “Kompetensi Umpan Balik Mahasiswa Praktikan PPL Pendidikan Jasmani". Laporan Penelitian. Surakarta: FKIP UNS.

. 2001. “Pemantapan kompetensi Pemberian Umpan Balik Praktikan melalui Skenario PPL Pendidikan Jasmani". Jurnal Ilmiah VARIDIKA, Vol. XIII NO. 22, Juli 2001. Akreditasi Nasional.

. 2005. Kualitas Harapan dan kesiapan mahasiswa prodi Penjaskesrek dalam Pelaksanaan Program Pengalaman Lapangan (PPL) tahun 2005. Laporan Penelitian.Surakarta: FKIP UNS.

1997. "Spektrum Gaya Mengajar Pendidikan Jasmani". Jurnal Dwijawarta. Edisi April-Juni: hal. 4044.

2004. "Aplikasi Model Pembelajaran Sibernetika Pendidikan Jasmani". Jurnal Ilmiah IPTEK Olahraga, Volume 6 Nomor 2, Mei 2004. Akreditasi Nasional. Diterbitkan Oleh: Direktorat
Pemberdayaan IPTEK Olahraga Direktorat Jenderal Olahraga Depdiknas RI.

. 2004. “Peningkatan Kompetensi Mengajar Pendidikan Jasmani melalui Perbaikan Pilihan Spektrum Gaya Mengajar (The spectrum of Teaching Style) Model Mosston". Laporan Penelitian.Jakarta:DPPM/CAR/

LPTK/Direktorat Jenderal Pendidikan Tinggi.

Kristiyanto, Agus. dkk, 1998. "Akuntabilitas PPL pendidikan jasmani". Laporan Penelitian. Surakarta: FKIP UNS.

Dauer, V. and Pangrazi, R. 1986. Dynamic Physical Education. London: Macmillan Publisher.

Drowatzky, John N., 1991. Motor Learning: Principles and Practices. Mineapolis: Burgess Publishing Company.

Mappasoro, 1998, Tahun II. “Peningkatan Keterampilan Bertanya Guru dalam Mengelola PBM Mata Pelajaran IPS". Jurnal Penelitian Pendidikan Dasar. No. 5: 41-53.

Margono, Agus, dkk. 2005. “Diagnosis kesulitan penguasaan komponen keterampilan mengajar pada mahasiswa JPOK FKIP UNS tahun 2005. Laporan Penelitian. Surakarta: FKIP UNS. 
Mosston, Muska, 2000. Teaching Physical Education. Illinois: Columbus L Bell and Howell Companies.

Upe, Ambo \& Damsid, 2010. Asasasas Multiple Researches. Yogyakarta: Tiara Wacana.

Wardani, I.G.K. dan Suhaenah, Ana. 1994. Program Pengalaman Lapangan. Jakarta: $P_{3}$ MTK Ditjen Dikti Depdikbud. 